\title{
LET'S TALK ABOUT IT
}

\section{Acceleration of bone cell movements by micropulse stimulation on roots: fantasy or reality?}

\author{
M. Amoric
}

The acceleration of bone cell movements is a persistent concern among practitioners and researchers. If rendered possible, it would limit dental caries, radicular resorption, or certain kinds of aggressive periodontitis. It would improve patient cooperation.

In addition to applying electrical currents or injecting prostaglandin E2 and calcium gluconate, using individual fasteners af-

\section{LITERATURE REVIEW}

The efficacy of the Insignia ${ }^{\circledR}$ system was presented by Weber et al. In 35 patients treated with the Insignia ${ }^{\circledR}$ system compared to 11 patients treated in the conventional manner, they concluded that the results obtained with Insignia ${ }^{\circledR}$ were closer to those defined by the American Board of Orthodontics and fects the speed of treatments [Insignia ${ }^{\circledR}$ (Ormco) or Suresmile ${ }^{\circledR}$ (OraMetrix)].

This aim of treating patients more quickly is now enriched with a micropulse vibrator applied to the roots (Acceledent ${ }^{\circledR}$ ). Howev$\mathrm{er}$, is this new process really effective?

To answer this question, we go through all publications devoted to this subject to form an opinion on the current state of knowledge.

that the average treatment time was significantly shorter (14.23 months versus 22.91 months for conventionally treated patients).

In a recent study, Moles reported that the average treatment time with Suresmile ${ }^{\circledR}$ was shorter than average treatment time without Suresmile ${ }^{\circledR}$.

Address for correspondence:

Michel Amoric

Article received: 15-09-2016.

E-mail:michel.amoric@wanadoo.fr Accepted for publication: 30-09-2016.

This is an Open Access article distributed under the terms of the Creative Commons Attribution License (http://creativecommons.org/licenses/by/4.0), which permits unrestricted use, distribution, and reproduction in any medium, provided the original work is properly cited. 
Saxe et al. compared the treatment time of 38 patients treated with Suresmile $^{\circledR}$ with 24 patients treated in a traditional way. They revealed that patients treated with Suresmile ${ }^{\circledR}$ had a faster and improved quality of treatment.

Alford et al. compared the treatment time and outcome of 69 patients treated with Suresmile ${ }^{\circledR}$ with 63 patients treated in a conventional manner. They found that the treatment time with Suresmile ${ }^{\circledR}$ was shorter.

Sachdeva et al. showed that Suresmile ${ }^{\circledR}$ treatment times were statistically shorter $(p<0.001)$.

In 2014, Bowman indicated that alignment and leveling in the Acceledent $^{\circledR}$ micropulse stimulation group appeared faster than that in the control group.

Woodhouse et al. (International \& American Associations for Dental Research, 2015) recently published a randomized clinical trial in which they found that using micropulse stimulation does not reduce the time required to achieve suitable results.

Pavlin et al. compared two groups: one receiving micropulse stimulation

\section{DISCUSSION}

To say that "cooperation" is the parameter that dominates the speed of a treatment is an aporia.

When patients perceive unbearable pain, they react by not wearing elastic bands or by breaking their appliances, which will slow down their treatment.

Several studies have investigated whether the root micropulse stimulator is able to lessen the pain caused by orthodontic devices.

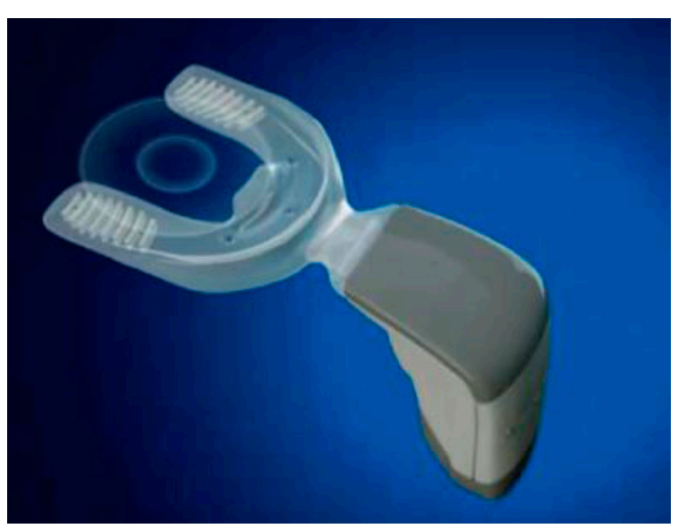

The root micropulse stimulator Acceledent ${ }^{\circledR}$

(OrthoAccel Technologies, Inc., Bellaire, TX, United States)

and the other a placebo (no stimulation). Of the 45 patients tested, the interval between confidence averages did not allow a statistically significant relationship to be established. In a time study comparing Insignia ${ }^{\circledR}$, Suresmile ${ }^{\circledR}$, and Acceledent ${ }^{\circledR}$, Abdullah showed that only treatment with Suresmile ${ }^{\circledR}$ reduced the treatment time. The effectiveness of the micropulse stimulator on the roots has therefore not been proven.

Woodhouse et al. conducted a randomized prospective study of 80 patients below 20 years of age to test the analgesic capacity of Acceledent ${ }^{\circledR}$ micropulse stimulation. They concluded that this device had no effect on orthodontic pain or associated analgesic consumption during initial alignment with fixed devices.

In another study having a high methodological quality, Woodhouse et al. arrived at the same conclusion? 


\section{CONCLUSION}

Published data available do not allow us to conclude that root micropulse stimulators are effective for reducing treatment time or pain. Although retrospective studies have suggested that Suresmile ${ }^{\circledR}$ treatments are capable of accelerating the treatment time, these means always remain under the overriding dependence of cooperation of patients. It is not impossible that articles having potential conflicts with manufacturers try to persuade us otherwise.

Conflict of interest: The author declares that there is no conflict of interest.

1. "This prospective randomized clinical trial found no evidence that supplemental vibrational force with an AcceleDent ${ }^{\circledR}$ removable device can reduce pain or the consumption of analgesics during the alignment phase of fixed appliance orthodontic treatment."

\section{BIBLIOGRAPHY}

1. Amoric A. Les vibrations, Poésie. Paris : L. Vanier Ed., 1892.

2. Amoric M. Des solutions techniques à la panne de coopération. Am J Orthod Dento-fac Orthop, Ed. Fr. 1991;1:41-44.

3. Aldrees AM. Do customized orthodontic appliances and vibration devices provide more efficient treatment than conventional methods? Korean J Orthod 2016;46(3):180-185.

4. Alford TJ, Roberts WE, Hartsfield JK, Jr, Eckert GJ, Snyder RJ. Clinical outcomes for patients finished with the SureSmileTM method compared with conventional fixed orthodontic therapy. Angle Orthod 2011;81:383388.

5. Bowman SJ. The effect of vibration on the rate of leveling and alignment. J Clin Orthod 2014;48:678-688.

6. Gracco A, Stellini E, Parenti SI, Bonetti GA. Individualized orthodontic treatment: The Insignia system. Orthodontics (Chic.) 2013;14(1):e88-e94.

7. Kau CH, Nguyen JT, English JD. The clinical evaluation of a novel cyclical force generating device in orthodontics. Orthod Pract US 2010;1:10-15.

8. Moles R. The SureSmile system in orthodontic practice. J Clin Orthod 2009;43:161-174.

9. Pavlin D, Anthony R, Raj V, Gakunga PT. Cyclic loading (vibration) accelerates tooth movement in orthodontic patients: a double-blind, randomized controlled trial. Semin Orthod 2015;21:187-194.

10. Proffit WR. Accelerated tooth movement? Surgery first? Third molar management? (Lecture); Paper presented at: 114th Annual Session of the American Association of Orthodontists 2014 Apr 25-29; New Orleans.

11. Sachdeva RC, et al. Treatment time: SureSmile vs conventional. Orthodontics (Chic.) 2012;13(1):72-85.

12. Saxe AK, Louie LJ, Mah J. Efficiency and effectiveness of SureSmile. World J Orthod 2010;11(1):16-22. 
13. Weber DJ, 2nd, Koroluk LD, Phillips C, Nguyen T, Proffit WR. Clinical effectiveness and efficiency of customized vs. conventional preadjusted bracket systems. J Clin Orthod 2013;47(4):261-266.

14. Woodhouse NR, et al. Supplemental vibrational force during orthodontic alignment: a randomized trial. J Dent Res 2015;94(5):682-689.

15. Woodhouse NR, et al. Supplemental vibrational force does not reduce pain experience during initial alignment with fixed orthodontic appliances: a multicenter randomized clinical trial. Sci Rep 2015;5:17224. 